Thamrin, Syaiful, Analisis Kebisingan yang Ditimbulkan Kepadatan Kendaraan Bermotor

\title{
ANALISIS KEBISINGAN YANG DITIMBULKAN KEPADATAN KENDARAAN BERMOTOR (Studi kasus Depan Masjid Assalafiyah, JI. Raya Sukabumi KM 22 Cigombong, Kabupaten Bogor)
}

\author{
Thamrin, Syaiful \\ Program Studi Teknik Sipi, Fakultas Teknik, Universitas Ibn Khaldun
}

\begin{abstract}
ABSTRAK
Pengaruh tingkat kebisingan lalu lintas terhadap kepadatan lalu lintas memiliki korelasi yang baik, dengan jumlah kendaraan yang melewati di ruas jalan dapat dilihat dari hubungan yang cukup linier antara kedua variabel yaitu kebisingan lalu lintas dan kepadatan lalu lintas, diketahui bahwa terdapat variabel yang mempengaruhi tingkat kebisingan tersebut, diantaranya adalah kepadatan lalu lintas, lebar jalan, jenis kendaraan dan benda benda sekitar jalan yang dapat meredam atau mementulkan bunyi. Kepadatan kendaraan di sekitarnya memberikan konstribusi besar pada kebisingan yang di terima oleh Masjid Assalafiyah Cigombong, dengan kontribusi sebesar 68,281 dB. Tingginya kebisingan yang diterima asjid Assalafiyah Cigombong, dipengaruhi oleh banyaknya kendaraan yang melintas di ruas jalan Mayjen Edi Sukma KM 22 yang setiap 1 jam rata-rata sebanyak 3.874 kendaraan. Kebisingan yang diterima tersebut, selain dipengaruhi oleh banyaknya kendaraan yang melintas, dipengaruhi juga oleh lingkungan sekitar masjid. Kebisingan yang terjadi di lingkangan masjid sudah saatnya memerlukan penanganan yang serius, mengingat pengaruh buruk dari kebisingan terhadap kesehatan manusia pada akhirnya akan mempengaruhi kualitas hidup masyarakat. Berbagai penanganan kebisingan telah banyak dilakukan terutama terkait tiga hal, yaitu pada sumber suara, media suara dan penerima. Penanganan secara arsitektural lebih tepat ditunjukan pada penanganan media perambatan suara.
\end{abstract}

Kata-kata kunci: Kebisingan, kepadatan lalu lintas, sound level meter.

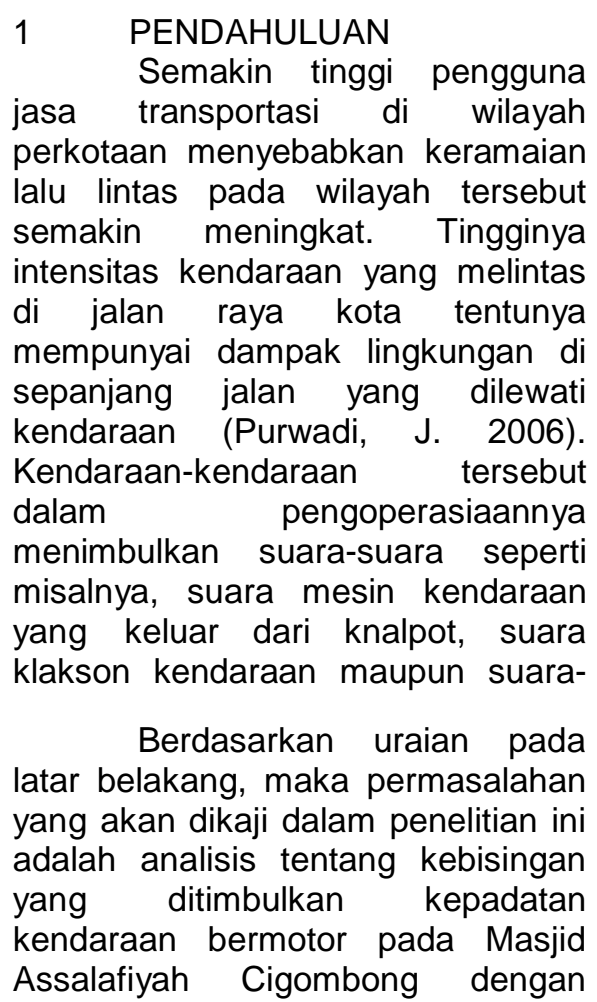

suara yang diakibatkan oleh aktivitas dari mesin kendaraan yang lainnya. Pada level tertentu suara-suara tersebut masih dapat ditoleransi oleh masyarakat, dalam artian suara yang diakibatkan masih tidak menimbulkan suatu gangguan kenyamanan dan gangguan lainnya terhadap masyarakat, akan tetapi pada tingkat yang lebih tinggi suara yang ditimbulkan oleh kendaraankendaraan transportasi tersebut sudah dapat dikatakan sebagai suatu gangguan yang disebut polusi suara atau kebisingan (Djalante, 2010).

program aplikasi SPSS. Penelitian ini bertujuan untuk mengetahui tingkat kebisingan di lingkungan Masjid Assalafiyah Cigombong, yang diduga akibat dari kepadatan lalu lintas jalan raya. 


\section{TINJAUAN PUSTAKA}

2.1

\section{Pengertian Tentang Jalan}

$\begin{array}{llr}\text { Jalan raya } & \text { adalah } \\ \text { merupakan } & \text { prasarana } \\ \text { transportasi } & \text { darat } & \text { yang } \\ \text { memegang } & & \end{array}$

peranan sangat penting dalam sektor perhubungan terutama untuk kesinambungan distribusi barang dan jasa. Fungsi jalan yaitu untuk melayani beban dan arus lalu lintas yang ada dan yang akan berkembang, dan dapat memberikan keamanan serta kenyamanan kepada pemakali jalan (Peraturan Dirjen Perhubungan Darat, 2007).

\subsection{Pengertian Tentang Kepadatan Kendaraan}

Kepadatan lalu lintas adalah kondisi arus lalu lintas yang didefinisikan

sebagai jumlah kendaraan yang menempati suatu ruas jalan atau lajur, yang biasanya dinyatakan dalam suatu kendaraan per kilometer atau kendaraan per kilometer per lajur (Departemen Pekerjaan Umum Direktorat Bina Marga, 1997). Kepadatan lalu lintas (D) terhadap kebisingan sangat berpengaruh, hal ini bisa dipahami karena tingkat kebisingan lalu lintas Kepadatan (D) dihitung dengan persamaan berikut:

$\mathbf{D}=\frac{\boldsymbol{Q}}{\boldsymbol{U} \boldsymbol{s}}$ merupakan harga total dari beberapa tingkat kebisingan dimana masingmasing jenis kendaraan mempunyai tingkat kebisingan yang berbedabeda. Tingginya kepadatan lalu lintas kendaraan dapat menurunkan kualitas lingkungan yang diakibatkan oleh transportasi tersebut, antara lain kebisingan dan polusi (Ofyar Z, Tamin, 1992). Namun demikian kepadatan dapat dihitung dari kecepatan dan volume, yang mempunyai bentuk hubungan sebagai ditunjukan pada rumus berikut :

Keterangan :

$\mathrm{D}=$ Kepadatan lalu lintas [kend $/ \mathrm{km}]$

$\mathrm{Q} \quad=$ Volume lalu lintas [kend/jam]

Us $\quad$ Kecepatan lalu lintas $[\mathrm{km} / \mathrm{jam}]$ 


\subsection{Hubungan antara kecepatan, volume dan kepadatan lalu lintas}

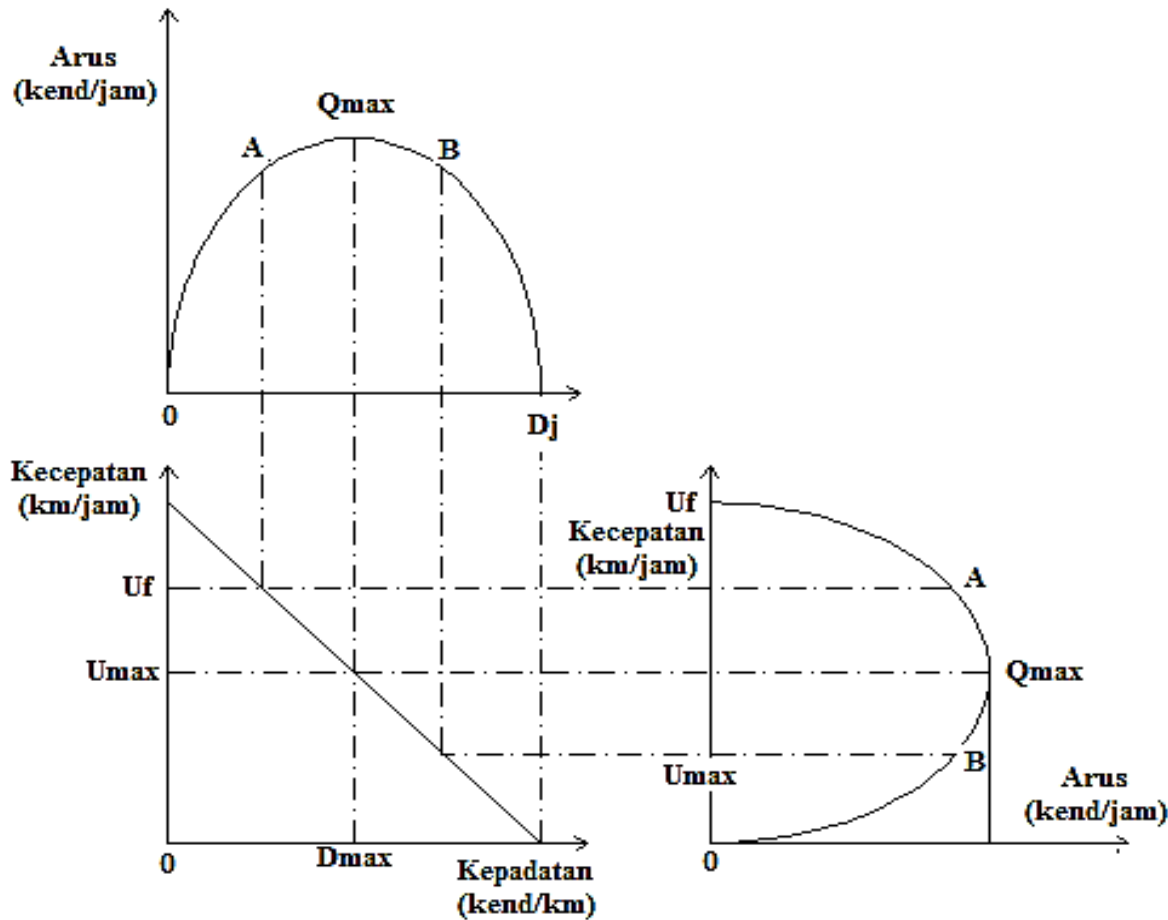

Gambar 1 Grafik Hubungan kecepatan, volume dan kepadatan

1) Hubungan kecepatan dan volume

Hubungan mendasar antara kecepatan volume adalah dengan bertambahnya volume lalu-lintas maka kecepatan ratarata ruangnya akan berkurang sampai kepadatan kritis (volume maksimum) tercapai. Setelah kepadatan tercapai maka kecepatan rata-rata ruang dan volume akan berkurang.

2) Hubungan volume dan kepadatan Volume maksimum terjadi (Qm) pada saat kepadatan mencapai titik Dm (kapasitas jalur jalan sudah tercapai).

\subsection{Pengertian Kebisingan}

$\begin{array}{lr}\text { Menurut } & \text { Keputusan } \\ \text { Menteri Negara } & \\ \text { Lingkungan Hidup } & \text { Kep- } \\ \text { 48/MENLH/11/1996, yang } & \text { yan } \\ \text { dimaksud dengan kebisingan } \\ \text { adalah bunyi yang tidak } \\ \text { diinginkan dari usaha atau } \\ \text { kegiatan dalam tingkat dan } \\ \text { waktu tertentu yang dapat } \\ \text { menimbulkan gangguan } \\ \text { kesehatan manusia dan }\end{array}$

Setelah mencapai titik ini volume akan menurun walaupun kepadatan bertambah sampai terjadi kemacetan ditik Dj.

3) Hubungan kecepatan dan kepadatan

Kecepatan akan menurun apabila kepadatan bertambah. Kecepatan arus bebas akan terjadi apabila kepadatan sama dengan nol dan pada saat kecepatan sama dengan nol maka akan terjadi kemacetan (jam density).

kenyamanan lingkungan.

Pertumbuhan transportasi darat, laut, dan udara yang cepat, kebisingan telah menjadi faktor lingkungan yang sangat penting di kota-kota, dan bukanlah sesuatu 
yang tidak realistik untuk meramalkan bahwa daerah pedesaan pun akan dipengaruhi oleh bising pada masa yang akan datang.

\subsubsection{Jenis kebisingan}

Berdasarkan asal sumber, kebisingan dapat diklasifikasikan menjadi 4 macam kebisingan, (Kepmen LH No.48 Tahun 1996).

1) Kebisingan impulsif, yaitu kebisingan yang datangnya tidak secara terus menerus, akan tetapi sepotong-sepotong. Contohnya: Kebisingan yang datang dari suara mesin pemancang tiang pancang.

2) Kebisingan kontinyu, yaitu kebisingan yang datangnya secara terus menerus dalam waktu yang cukup lama.

Contohnya: Kebisingan yang datang dari suara mesin yang dihidupkan.

3) Kebisingan semi kontinyu, yaitu kebisingan kontinyu yang hanya sekejap, kemudian hilang dan mungkin akan datang lagi. Contohnya: Kebisingan yang datang dari suara mobil atau pesawat terbang yang sedang lewat.

Tabel 1 Batas nilai tingkat kebisingan.

\begin{tabular}{|l|c|}
\hline Peruntukan kawasan / Lingkungan & Tingkat kebisingan (dBA) \\
\hline kesehatan & 55 \\
1. Peruntukan kawasan & 70 \\
a. Perumahan dan pemukiman b. & 65 \\
Perdagangan dan jasa & 50 \\
c. Perkantoran dan perdagangan d. & 70 \\
Ruang terbuka hijau & 60 \\
e. Industri & 70 \\
f. Pemerintahan dan fasilitas umum g. & \\
Rekreasi & \\
& 55 \\
\hline 2. Lingkup kegiatan & 55 \\
a. Rumah sakit atau sejenisnya b. & 55 \\
Sekolah atau sejenisnya & \\
c. Tempat ibadah atau sejenisnya & \\
\hline
\end{tabular}

(Sumber: Menteri Negara Lingkungan Hidup, 1996)

\section{TATA KERJA}

\subsection{Waktu dan Tempat Penelitian}

Waktu penelitian ini dilakukan pada tanggal 19 Maret 2014 sampai 23

Maret 2014. Pengambilan data lalu lintas dilakukan setiap hari, dengan tidak mengkhususkan hari-hari tertentu, seperti hari sanbtu dan minggu. Penelitian ini di lakukan pada jalan Mayjen HR Edi Sukma KM 22. Lokasi pengambilan data lalu lintas di tunjukan pada Gambar 2. dan Gambar 3. 
Thamrin, Syaiful, Analisis Kebisingan yang Ditimbulkan Kepadatan Kendaraan Bermotor
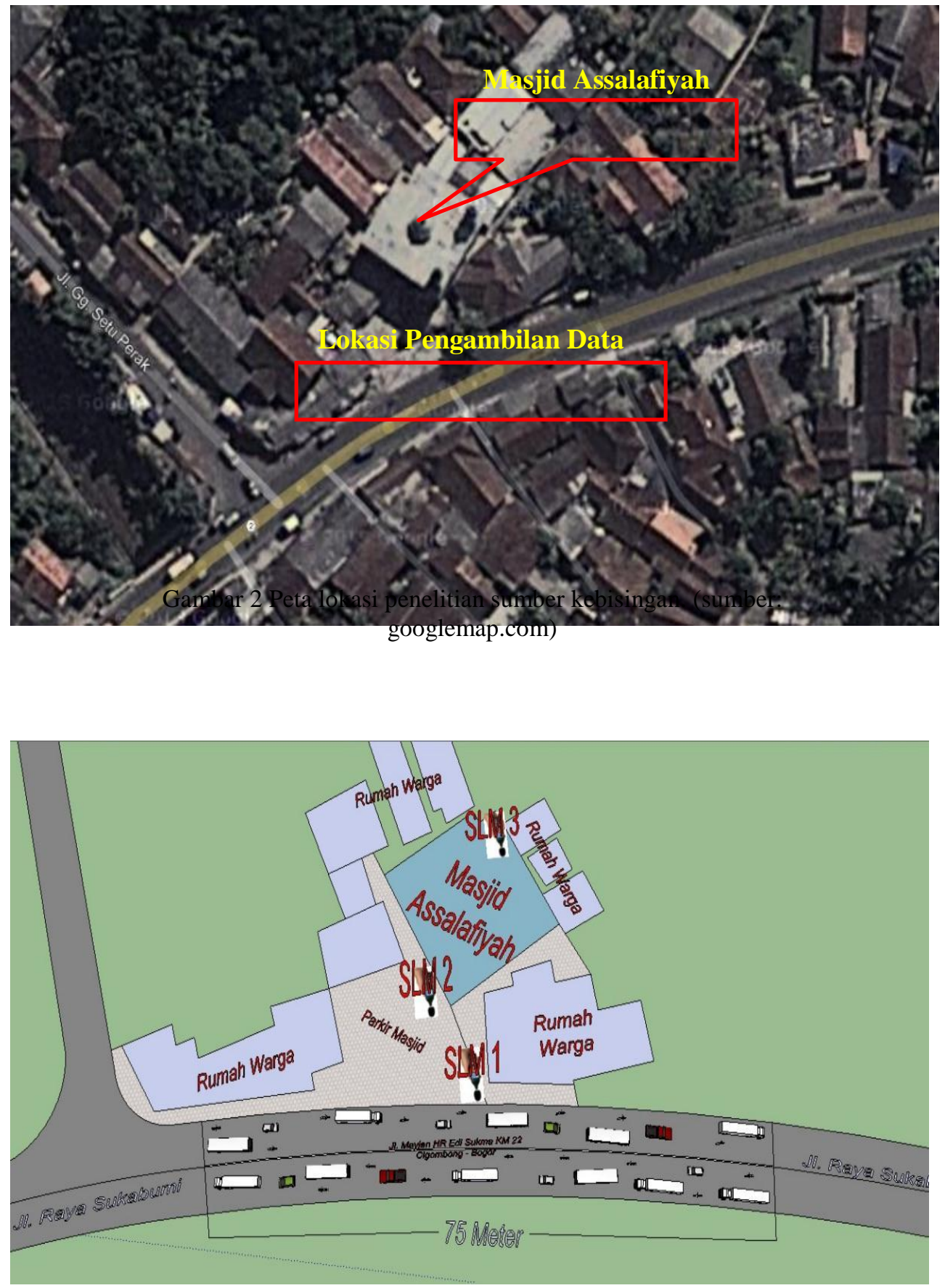

Gambar 3 Site plan lokasi pengambilan data. 


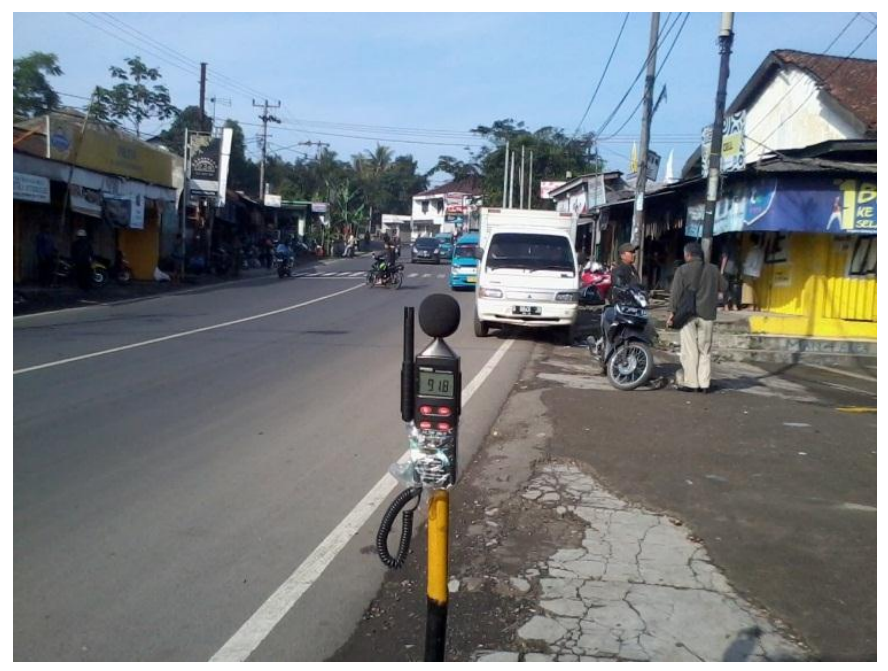

Gambar 4 Posisi SLM 1

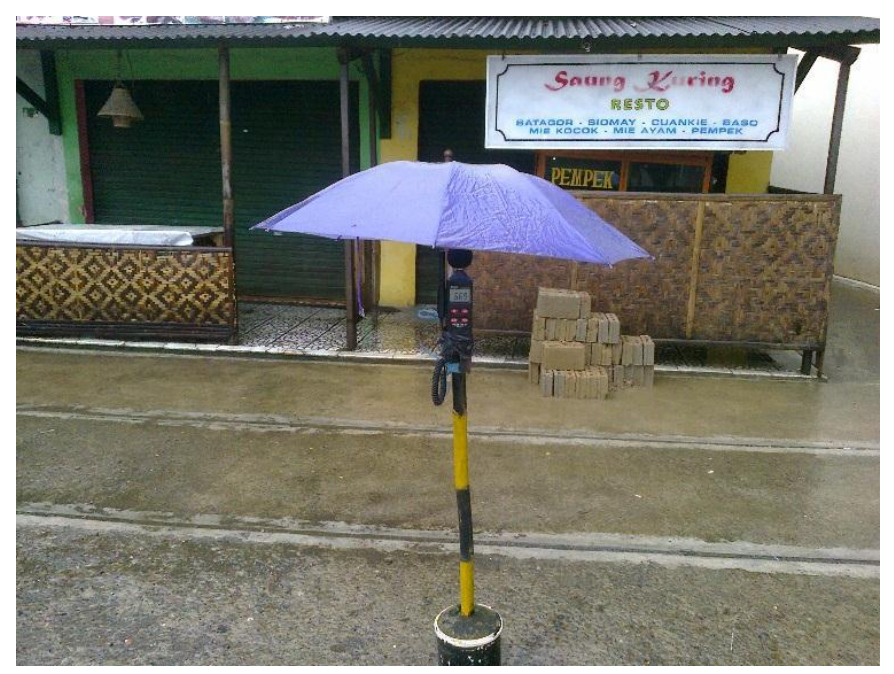

Gambar 5 Posisi SLM 2

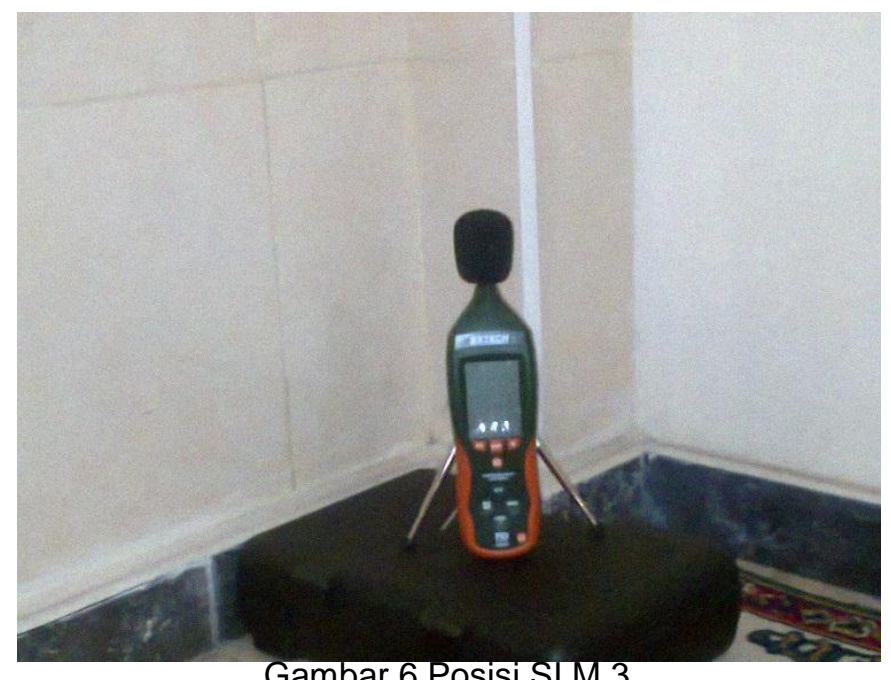

Gambar 6 Posisi SLM 3 


\subsection{Metode Penelitian}

Metode yang akan digunakan dalam

pelaksanaan penelitian diuraikan sebagai

berikut :

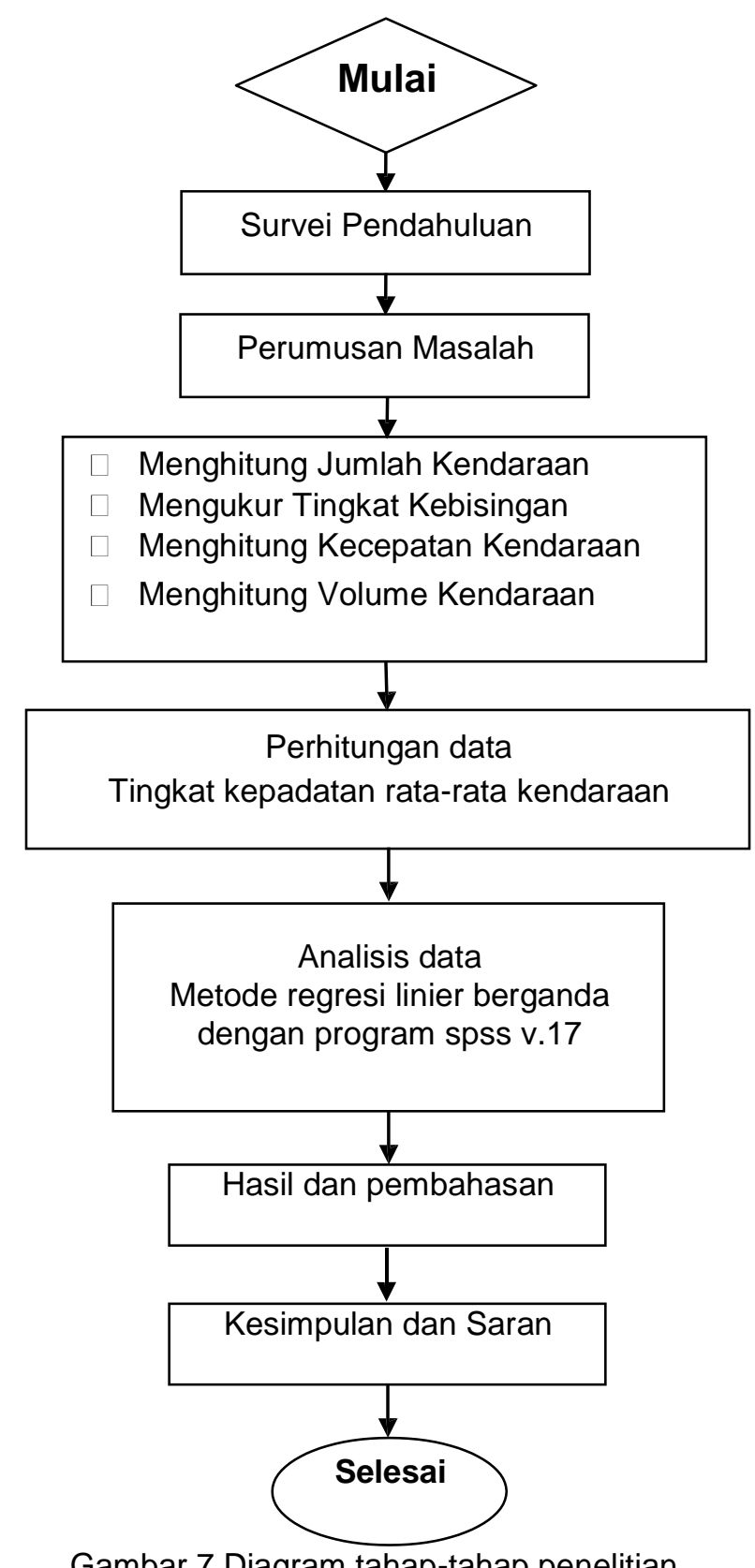

Gambar 7 Diagram tahap-tahap penelitian

4. HASIL DAN PEMBAHASAN

\subsection{Hasil Data Lapangan}

Data hasil lalu lintas yang di

19 Meret 2014, hari

hitung adalah data per 15

menit selama 12

jam dalam sehari. Data di ambil mulai dari pukul 6.00 sampai pukul

18.00. Data ini di ambil selama 4

hari, yaitu pada hari Rabu tanggal 
Jum'at tanggal 21 Maret 2014, hari Sabtu tanggal 22 Maret 2014, dan hari

Minggu 23 Maret 2014.

Perhitungan hasil pengolahan kepadatan berdasarkan panduan

Kepadatan mobil pribadi perhitungan kepadatan dari Dinas Bina Marga Departemen Pekerjaan Umum Republik Indonesia. Pengambilan data dimulai dengan menghitung kepadatan dari rumus seperti dibawah ini :

$$
\begin{aligned}
(\mathrm{D}) & =\frac{\text { Volume (Q) }}{\text { Kecepatan (Us) }} \\
\mathrm{D} & =\text { Kend./km }
\end{aligned}
$$

Ditampilkan salah satu contoh perhitungan kepadatan untuk sepeda motor pada hari pertama Rabu 19 Maret

2014 untuk perhitungan menit pertama $06.00-06.15$ adalah :

Diketahui :

Jadi

$$
\begin{array}{ll}
\text { Volume (Q) } & =3968,00 \mathrm{kend} / \mathrm{jam} \\
\operatorname{Kecepatan}(\mathrm{Us}) & =22,13 \mathrm{~km} / \mathrm{jam}
\end{array}
$$

Didapatkan

$$
\text { Kepadatan }(\mathrm{D}) \quad=\quad \underline{\text { Volume }(\mathrm{Q})}
$$

$$
\text { Kecepatan (Us) }
$$

hasil

$$
\text { Kepadatan (D) = } \quad=179,29 \text { kend. } / \mathrm{km}
$$

$$
\begin{gathered}
=\frac{3968,00}{\mathrm{kend} . / \mathrm{jam}} \\
22,13 \\
\mathrm{~km} / \mathrm{jam}
\end{gathered}
$$

4.2 Kepadatan kendaraan dan tingkat kebisingan pada Sound Level Meter

(SLM) hari Rabu Tanggal 19 Maret 2014

Dari hasil perhitungan data kepadatan kendaraan dan tingkat kebisingan pada Sound Level Meter yang diperoleh di lapangan maka didapatkan kepadatan ratarata kendaraan per 15 menit per hari yang ditunjukkan dalam gambar sebagai berikut:

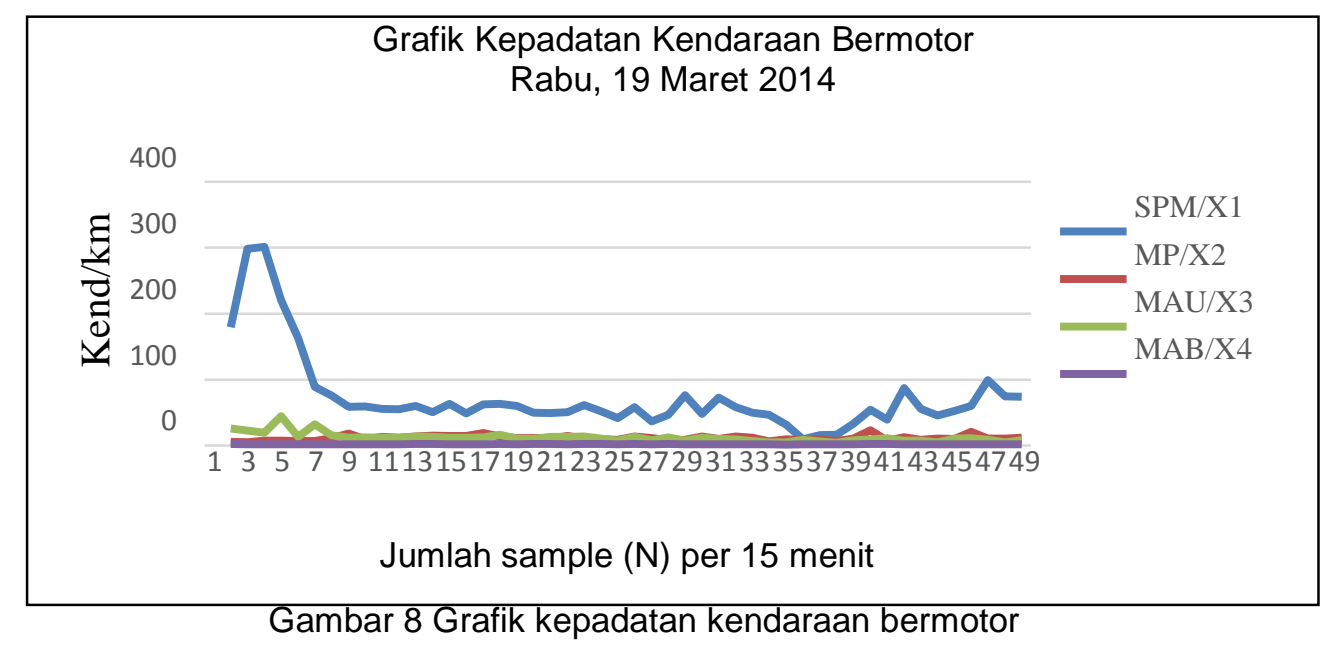


Berdasarkan grafik di atas menunjukkan bahwa kepadatan kendaraan bermotor pada hari Rabu per 15 menit yang memiliki kepadatan rata-rata tertinggi adalah pertama sepeda motor (SPM/X1) sebesar $72,83 \mathrm{kend} / \mathrm{km}$, kedua mobil angkutan umum (MAU/X3) sebesar 11,84 $\mathrm{kend} / \mathrm{km}$, ketiga mobil pribadi (MP/X2) sebesar 10,88 $\mathrm{kend} / \mathrm{km}$, dan terakhir mobil angkutan barang (MAB/X4) sebesar 1,63 $\mathrm{kend} / \mathrm{km}$.

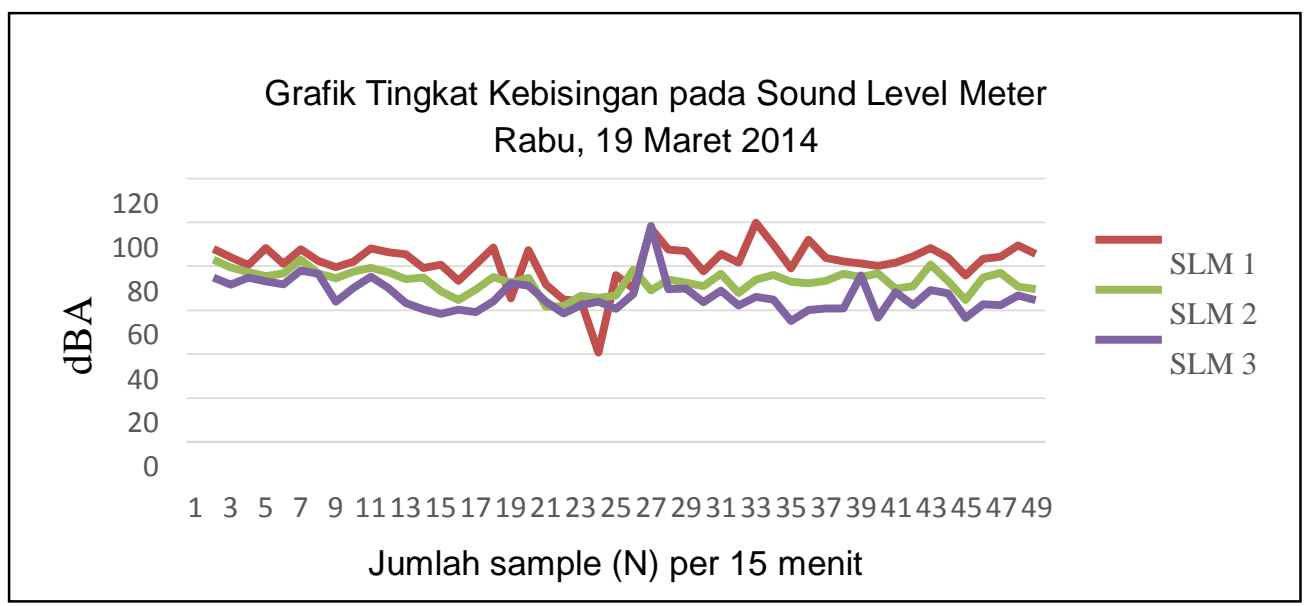

Gambar 9 Grafik tingkat kebisingan pada SLM

Sedangkan untuk grafik tingkat rata-rata kebisingan per 15 menit terbesar terjadi pada SLM 1 sebesar 81,66 dBA, kemudian pada SLM 2 sebesar 73,19 dBA, dan SLM 3 sebesar 66,64 dBA.

\subsection{Kepadatan kendaraan dan tingkat kebisingan pada Sound Level Meter (SLM) hari Jum'at Tanggal 21 Maret 2014}

Dari hasil perhitungan data kepadatan kendaraan dan tingkat kebisingan pada Sound Level Meter yang diperoleh di lapangan maka didapatkan kepadatan rata-rata kendaraan per 15 menit per hari yang ditunjukkan dalam gambar sebagai berikut:

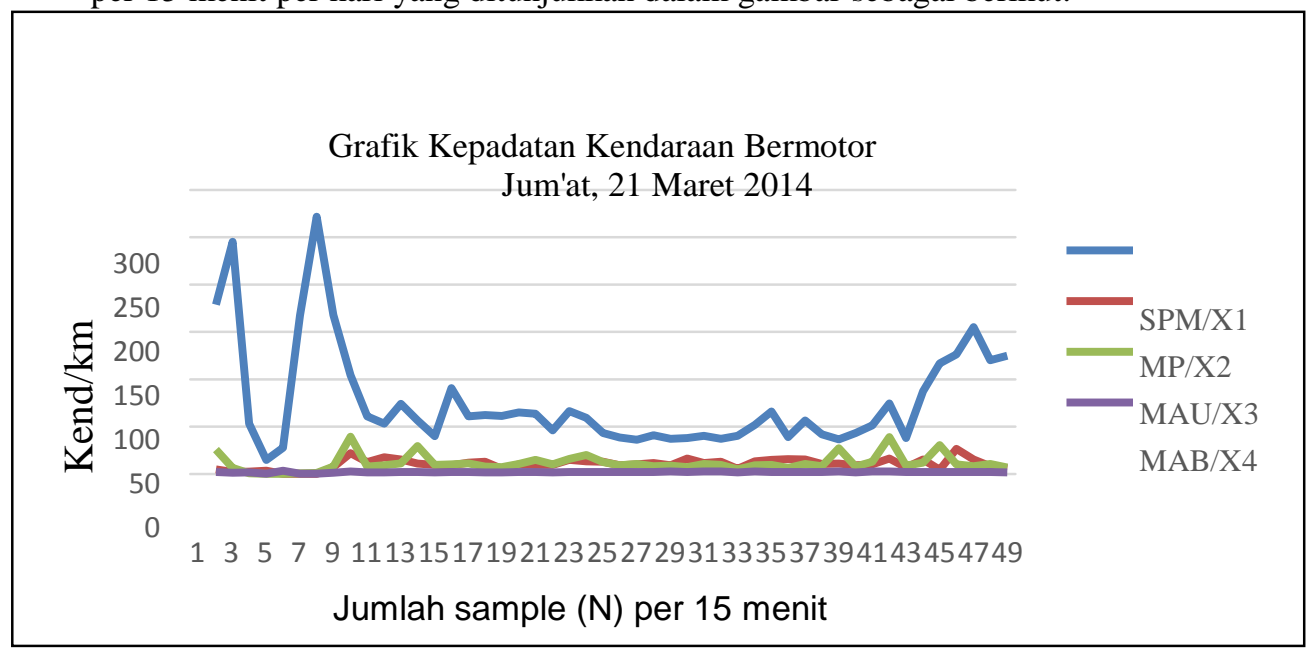

Gambar 10 Grafik kepadatan kendaraan bermotor

Berdasarkan grafik di atas menunjukkan bahwa kepadatan kendaraan bermotor pada hari Jum'at per 15 menit yang memiliki kepadatan rata-rata tertinggi adalah pertama sepeda motor (SPM/X1) sebesar $76,43 \mathrm{kend} / \mathrm{km}$, kedua 
mobil angkutan umum (MAU/X3) sebesar 11,47 kend/km, ketiga mobil pribadi (MP/X2) sebesar 10,41 kend/km, dan terakhir mobil angkutan barang (MAB/X4) sebesar 1,78 $\mathrm{kend} / \mathrm{km}$.

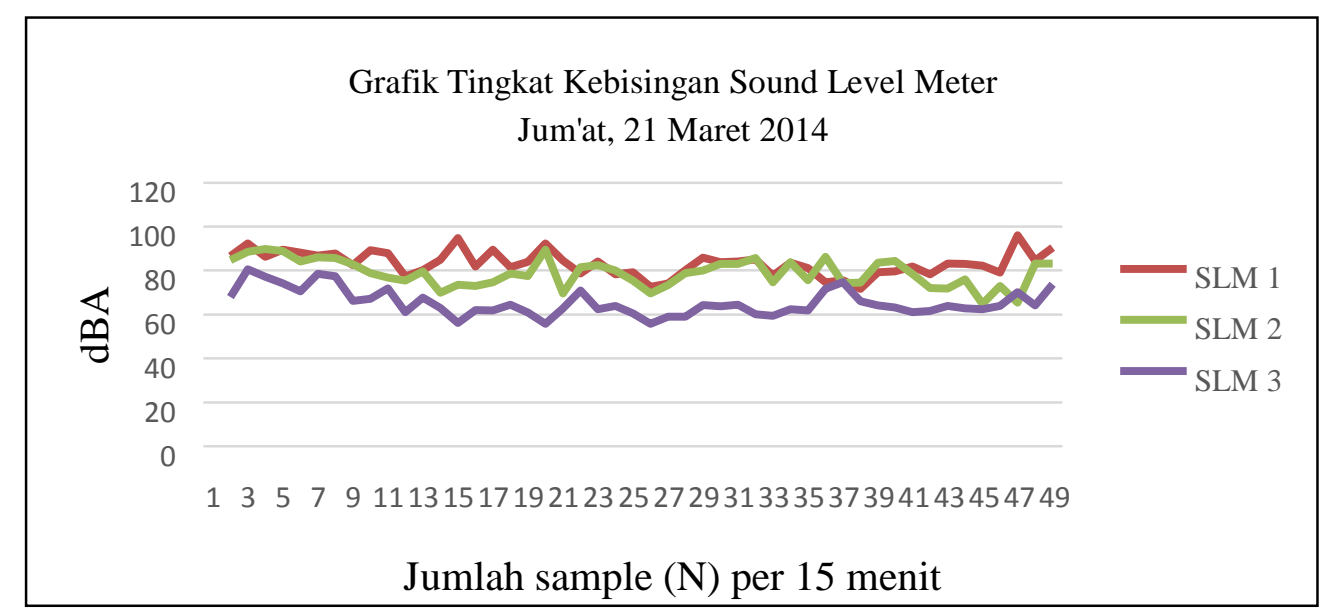

\section{Gambar 11 Grafik tingkat kebisingan pada \\ SLM}

Sedangkan untuk grafik tingkat rata-rata kebisingan per 15 menit terbesar terjadi pada SLM 1 sebesar 83,27 dBA, kemudian pada SLM 2 sebesar 78,88 dBA, dan SLM 3 sebesar 65,34 dBA.

\subsection{Kepadatan kendaraan dan tingkat kebisingan pada Sound Level Meter (SLM) hari Sabtu Tanggal 22 Maret 2014}

Dari hasil perhitungan data kepadatan kendaraan dan tingkat kebisingan pada Sound Level Meter yang diperoleh di lapangan maka didapatkan kepadatan rata-rata kendaraan per 15 menit per hari yang ditunjukkan dalam gambar sebagai berikut:

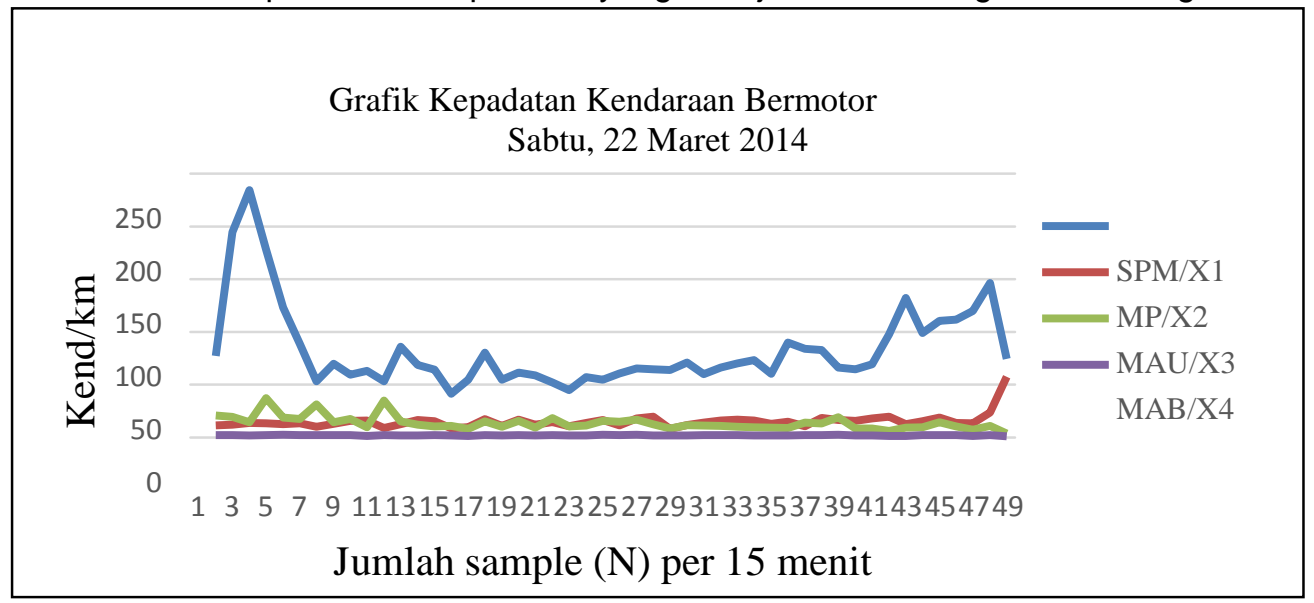

Gambat 12 Grafik kepadatan kendaraan bermotor

Berdasarkan grafik di atas menunjukkan bahwa kepadatan kendaraan bermotor pada hari Sabtu per 15 menit yang memiliki kepadatan rata-rata tertinggi adalah pertama sepeda motor (SPM/X1) sebesar 82,73 kend/km, kedua mobil pribadi (MP/X2) sebesar $14,91 \mathrm{kend} / \mathrm{km}$, ketiga mobil angkutan umum (MAU/X3) sebesar 13,54 $\mathrm{kend} / \mathrm{km}$, dan terakhir mobil angkutan barang (MAB/X4) sebesar 1,79 kend/km. 


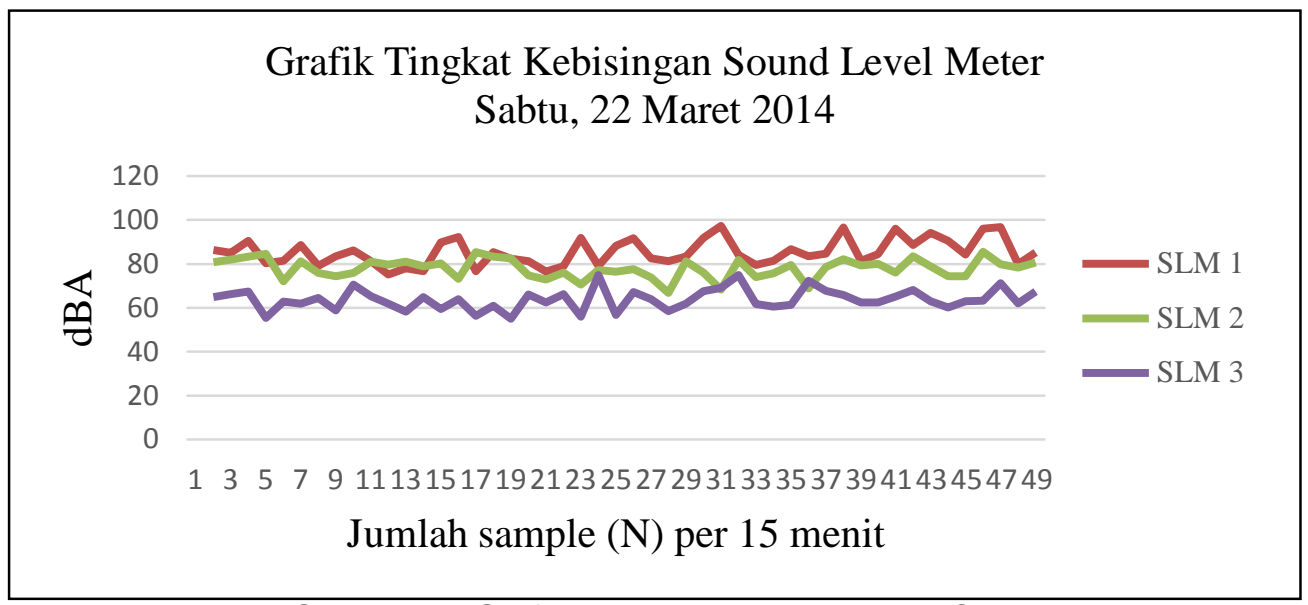

Gambar 13 Grafik tingkat kebisingan pada SLM

Sedangkan untuk grafik tingkat rata-rata kebisingan per 15 menit terbesar terjadi pada SLM 1 sebesar 85,24 dBA, kemudian pada SLM 2 sebesar 77,84 dBA, dan SLM 3 sebesar 63,70 dBA.

\subsection{Kepadatan kendaraan dan tingkat kebisingan pada Sound Level Meter (SLM) hari Minggu Tanggal 23 Maret 2014}

Dari hasil perhitungan data kepadatan kendaraan dan tingkat kebisingan pada Sound Level Meter yang diperoleh di lapangan maka didapatkan kepadatan ratarata kendaraan per 15 menit per hari yang ditunjukkan dalam gambar sebagai berikut:

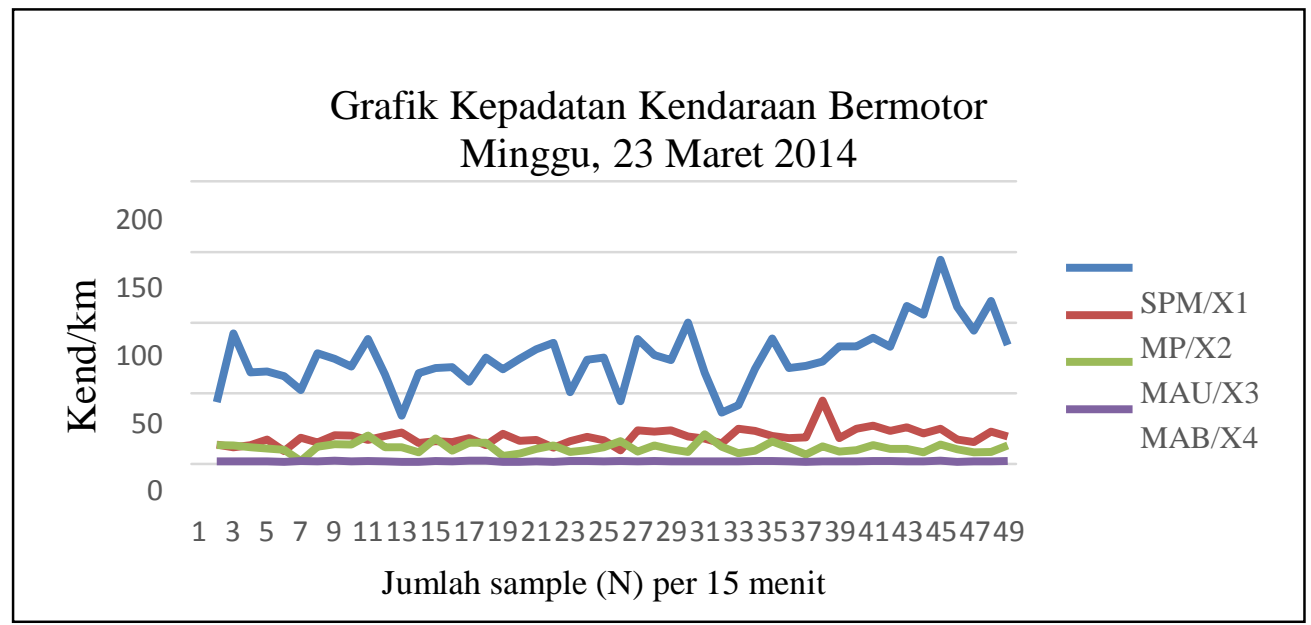

Gambar 14 Grafik kepadatan kendaraan bermotor

Berdasarkan grafik di atas menunjukkan bahwa kepadatan kendaraan bermotor pada hari Minggu per 15 menit yang memiliki kepadatan rata-rata tertinggi adalah pertama sepeda motor (SPM/X1) sebesar 75,58 kend/km, kedua mobil pribadi (MP/X2) sebesar 19,04 kend/km, ketiga mobil angkutan umum (MAU/X3) sebesar 11,25 kend/km, dan terakhir mobil angkutan barang (MAB/X4) sebesar 1,67 kend/km. 
Sedangkan untuk grafik tingkat rata-rata kebisingan per 15 menit terbesar terjadi pada SLM 1 sebesar 83,43 dBA, kemudian pada SLM 2 sebesar 74,19 dBA, dan SLM 3 sebesar 62,51 dBA.

\subsection{Pembahasan analisis statistik data kebisingan}

Analisis dan pengolahan data menggunakan SPSS versi 17 tingkat kebisingan (y), kepadatan sepeda motor (spm/x1), kepadatan mobil pribadi (map/x2), kepadatan mobil angkutan umum (mau/x3) dan kepadatan mobil angkutan barang $(\mathrm{mab} / \mathrm{x} 4)$ berdasarkan tingkat kepercayaan 95\%. Hasil persamaan dengan menggunakan data diatas disajikan dalam bentuk persamaan regresi linier berganda.

\section{KESIMPULAN}

Berdasarkan hasil penelitian yang telah dilakukan, di lingkungan yang berdekatan dengan jalan raya di Masjid Assalafiyah Cigombong, dapat disimpulkan bahwa sumber bunyi yang dihasilkan dari jalan raya tersebut terutama dari kendaraan bermotor yang melintas di sekitarnya memberikan kontribusi besar pada kebisingan yang di terima oleh Masjid Assalafiyah Cigombong. Tingkat kebisingan yang tertinggi pada hari kedua di titik ketiga (Sound Level Meter 3 ), dengan kontribusi sebesar 68,281 $\mathrm{dB}$, Tingginya kebisingan yang diterima Masjid Assalafiyah Cigombong, dipengaruhi oleh banyaknya kendaraan yang melintas di ruas jalan Mayjen Edi Sukma KM 22 yang setiap 1 jam rata-rata sebanyak 3.874 kendaraan. Kebisingan yang diterima tersebut, selain dipengaruhi oleh banyaknya kendaraan yang melintas, dipengaruhi juga oleh lingkungan (Syaiful, 2005). Berdasarkan ketentuan baku tingkat kebisingan, tingkat kebisingan yang diterima oleh lingkungan masjid tidak boleh melebihi nilai ambang batas yang ditentukan yaitu sebesar $55 \mathrm{~dB}$.
Dari hasil penelitian yang diperoleh, kebisingan yang diterima oleh Masjid Assalafiyah Cigombong, telah melebihi batas yang ditentukan, sehingga perlu dilakukan penanganan untuk mengurangi kebisingan yang diterima.

\section{DAFTAR PUSTAKA}

Departemen Pekerjaan Umum Direktorat Jenderal Bina Marga. 1997. Manual Kapasitas Jalan Indonesia (MKJI). Jakarta.

Djalante, Susanti. 2012. Analisis Tingkat Kebisingan Di Jalan Raya Yang Menggunakan Alat Pemberi Isyarat Lalu Lintas (APIL). Jurnal SMARTek, Vol. 8

No. 4. Kendari.

Menteri Negara Lingkungan Hidup. 1996. Baku Tingkat Kebisingan, SuratKeputusan Menteri Lingkungan Hidup Nomor : Kep-48/MENLH/1996/25 November 1996, Jakarta.

Ofyar, Z Tamin. 1992. Hubungan Volume, Kecepatan dan Kepadatan Lalu- lintas Di Ruas Jalan H.R. Rasuna Said Jakarta. Bandung: ITB.

Purwadi, J. 2006. Analisis Tingkat Kebisingan Dan Emisi Gas Buang Di Jalan Slamet Riyadi Dan Alternatif Solusinya (Kajian Empirikal dan Non Empirikal). Surakarta: Progam Magister Teknik Sipil Universitas Muhammadiyah.

Peraturan Direktur Jenderal Perhubungan Darat. 2007. Penetapan Nomor Rute Jalan Nasional Di Pulau Jawa, Peraturan Direktur Jenderal Perhubungan Darat Nomor: SK.930/AJ.401/DRJD/2007. Jakarta: Direkrut Jendral Perhubungan Darat

Syaiful, Syaiful, 2005, Analisis Kebisingan Arus Lalu Lintas Dan Geometri Jalan Di Kawasan Simpang Lima Kota Semarang. Masters thesis, program Pascasarjana Universitas Diponegoro. Diponegoro University, Semarang: INSTITUTIONAL REPOSITORY. 